\title{
Uniwersytet to akcelerator podziałów klasowych
}

\section{- z Andrzejem W. Nowakiem rozmawia Krystian Szadkowski}

Krystian Szadkowski: Dwadzieścia lat temu wydawało się, że Polska wkracza do królestwa wolności, w którym uniwersytety przestaną być poddawane ideologicznej indoktrynacji. Jak wyglądał w akademii ten okres upolitycznienia i jak reagowała ona na nadchodzące zmiany?

Andrzej W. Nowak: Rok 1989 oznaczał nadzieję wielkiej zmiany, także tej związanej z odpolitycznieniem życia akademickiego. Cenzura i upolitycznienie często wiązały się z trudnymi decyzjami, wpływały na przebieg karier akademickich, relacje ze studentami. Trafnie przedstawia to Krzysztof Zanussi w Barwach ochronnych. Ciekawsze jest jednak rozważenie, w jaki sposób komunistyczna ideologia wpływała na struktury wiedzy, kształt kierunków, ich obecność czy nieobecność w nauczaniu uniwersyteckim. Przykładem mogą być losy socjologii, która w latach pięćdziesiątych uznana została za naukę burżuazyjną, interesująca w tym kontekście jest także recepcja dorobku Floriana Znanieckiego. W filozofii zaowocowało to silnym rozwojem logiki, metodologii nauk, filozofii nauki, częściowo filozofii analitycznej. Dziedziny te mogły bowiem być rozwijane na wysokim poziomie jako stosunkowo wolne od bezpośredniego wpływu wątków wulgarnie ideologicznych. O wiele trudniej uprawiało się filozofię społeczną i polityczną, także tę lewicową. Losy marksistów rewizjonistycznych są tu bardzo symptomatyczne. Zatem tak - rok 1989 wiązał się rzeczywiście z nadzieja, że, mówiąc metaforycznie, niebo się rozchmurzy.

K.Sz.: Tymczasem okazało się, że funkcję państwa realnego socjalizmu przejął wolny rynek...

A.N.: ...na którego nadejście świat akademicki nie był w ogóle przygotowany. Pierwszym problemem było poważne zubożenie środowiska akademickiego. Wczesne lata dziewięćdziesiąte to dramatyczne wybory, które zmuszały akademików do najdziwniejszych „biznesów”. W Polsce sytuacja była i tak relatywnie mało dramatyczna, gdy porównamy ją z krajami byłego Związku Radzieckiego. Tam widok byłych akademików w rolach taksówkarzy czy sprzedawców przysłowiowej marchewki na bazarze nikogo nie dziwił. Sam znam z opowieści przypadek uczonego zza naszej wschodniej granicy, który po otrzymaniu pracy na jednej z polskich uczelni, jeździł w swe rodzinne strony i sprzedawał zbierane $\mathrm{w}$ Polsce ,reklamówki”. 
www.praktykateoretyczna.pl

Drugi problem wiąże się ściśle z ,kacem” po okresie upolitycznienia. Liberalny mit przejrzystości i neutralności sfery publicznej był bezapelacyjnie przyjęty jako jedyna „słuszna droga”. Myślenie krytyczne, lewicowe (np. feminizm) było traktowane jako powrót do przeszłości. To spowodowało, iż uniwersytet był bezradny wobec języka neoliberalnej ekonomizacji życia. Pozytywny, jak się wówczas zdawało, postulat neutralności, bezstronności jako postulat wolności od ideologii ( $\mathrm{w}$ domyśle minionego okresu) był funkcjonalny dla neoliberalnej strategii naturalizacji stosunków ekonomicznych. W ten sposób środowiska uniwersyteckie, poza kilkoma wyjątkami, takimi jak Tadeusz Kowalik, traktowały ekonomię i opisywane przez nią zjawiska jako zmienną niezależną.

\section{K.Sz.: Jaką rolę w transformacji ustrojowej odegrał uniwersytet?}

A.N.: Zacznijmy może od celnej wypowiedzi Ewy Charkiewicz, która we wprowadzeniu do dyskusji o neoliberalnym uniwersytecie stwierdziła, że „w polskich szkołach wyższych urynkowienie nałożyło się na stare postacie autorytaryzmu (hierarchie wiedzy, hierarchie pracownicze i pracowniczo-studenckie, władza profesorska). Uniwersytet odegrał i nadal odgrywa sprawczą rolę w transformacji, nadaje jej dyskursywny kształt i nadzoruje polityczne granice tego, jak i co można powiedzieć, a czego mówić nie można [...]. Rynek działa jak kryterium prawdziwościowe, wszystkie aspekty życia jednostek i życia społecznego są problematyzowane jako kwestie ekonomiczne, co skutkuje demokratycznym deficytem przez wykluczenie innych ujęć i poglądów".

Wymienić można przynajmniej trzy ważne aspekty negatywnego działania polskiej akademii w przemianach po 1989 roku. Z oczywistych względów myślę przede wszystkim o środowisku najbardziej mi znanym, czyli humanistyce i naukach społecznych. Po pierwsze, problemem polskiego uniwersytetu było jednoznaczne wspieranie ideologii neoliberalnej w diagnozowaniu polskich przemian. Wymienię tu dwa dominujące przejawy. Pierwszy związany jest z niewątpliwym podporządkowaniem polskiej myśli transformacyjnej teorii modernizacji i jej najnowszemu wcieleniu - dyskursowi o globalizacji. Uproszczona wizja stadialnej historii kazała witać przemiany po 1989 roku jako konieczne przejście do oczekiwanego i jak gdyby „gotowego” kapitalistycznego stadium historii. Okres PRL był opisywany jako swoista historyczna ,zamrażarka”. Brak było refleksji związanej z myślą alternatywną wobec teorii modernizacji, na przykład $\mathrm{z}$ teorią zależności czy teorią nowoczesnego systemu-świata.

\footnotetext{
${ }^{1} \mathrm{http}: / /$ www.ekologiasztuka.pl/seminarium.foucault/readarticle.php?article_id=112
} 
Drugim ważnym problemem było to, że szkolnictwo wyższe nie stało się w sposób oczywisty areną propagowania ideałów demokratycznych, egalitarnych, oświeceniowych. Szkolnictwo wyższe, szczególnie szkoły prywatne, nie kształcą obywatela. W wąsko i kapitalistycznie rozumianej modernizacji pożądanym rezultatem jest homo economicus. Mamy więc do czynienia ze zderzeniem pomiędzy obywatelem a uczestnikiem gry rynkowej. Oczywiste po 1989 roku założenie, iż są to postawy i tożsamości uzupełniające się, jest już dziś anachroniczne. Idee takie, jak równość szans, emancypacja, wyrównywanie zapóźnień rozwojowych, były pojmowane jako wyraz zacofania, wschodniej mentalności, gdyż utożsamiano je z socjalizmem. Przykładem było sprowadzanie postulatów feministycznych do hasła „kobiety na traktory”. Wiąże się z tym także kompromitujące wiernopoddańcze przywoływanie ideologicznych think tanków czy uczonych, jak Francis Fukuyama czy Samuel Huntington. Powoływanie się na koncept „wojny kultur” czy odgrzanie Feliksa Konecznego w kraju takich historyków, jak Witold Kula, Marian Małowist, jest zatrważającym przykładem upadku poziomu polskiej humanistyki.

\section{K.Sz.: Jakie zagrożenia dla idei uniwersytetu jako demokratycznej wspólnoty równych czy dla funkcjonowania wspólnoty społecznej przyniosła ideologia neoliberalna?}

A.N.: Podstawowe zagrożenie wiąże się z niezauważaną rolą uniwersytetu $\mathrm{w}$ procesie akceleracji rozwarstwienia społecznego. Można postawić ryzykowną tezę, iż szkolnictwo wyższe zamiast zacierać, zaostrza nierówności klasowe. Dzieje się tak przynajmniej na dwóch poziomach: jako część większej całości, jaką jest społeczeństwo, poprzez oddziaływanie środowisko akademickie zwiększa podziały zarówno na linii centrum/peryferie, miasto/wieś, jak i podziały wertykalne: klasa średnia/klasa niższa etc. Drugi poziom to podziały „klasowe” w obrębie samego uniwersytetu.

Zacznijmy od oddziaływania uniwersytetu na „zewnatrz”, jako aktora społecznego. Edukacja po 1989 roku przyczynia się do podważenia zasad współpracy i solidarności, ważnych i konstytutywnych zarówno dla możliwości uprawiania nauki, jak i demokracji. Uniwersytet staje się elementem kształcenia nowego neoliberalnego podmiotu, który siebie i innych traktuje w kategorii zasobów ludzkich. To przerażające stwierdzenie, które dla mnie brzmi jak przestroga przed powtórzeniem czasów, kiedy ludzie byli zasobem w najbardziej prymitywnym tego słowa znaczeniu.

\section{K.Sz.: W jaki sposób do tej pory uczelnie przystosowały się do wymogów rynkowych?}

A.N.: W konsekwencji strukturalnej i instytucjonalnej przemiany polskiego rynku szkolnictwa wyższego, studenci zostają $\mathrm{w}$ jego ramach przede wszystkim poddani przeobrażeniu w model ludzi neoliberalnych, ludzi sukcesu, zwolenników jednostkowej 
www.praktykateoretyczna.pl

emancypacji. Nauczanie zarządzania i marketingu, ekonomii i kierunków pokrewnych tłumaczone jest zapotrzebowaniem rynkowym. Jest to wbrew wszelkim danym statystycznym. Warto zapytać, czy te kursy przygotowują studentów do pracy w warunkach zatrudniania niepełnego czy wręcz do okresowego braku zatrudnienia. Czy niedoszli politolodzy, absolwenci zarządzania po 3-letnim licencjacie są przygotowani na załamanie się projektu jednostkowego sukcesu, który wdrukowywany był im w trakcie edukacji? Przewrotnie można powiedzieć, że chyba bardziej „rynkowym” byłoby uczenie filozofii. Kierunek ten pozwala, przynajmniej w niektórych przypadkach, na nauczenie się pewnej polityki własnej tożsamości. Powszechne nauczanie pedagogiki pełni zdaje się odrobinę inną funkcję. Z jednej strony, podobnie jak zarządzanie czy politologia, jest to kierunek „tani” potrzeba jedynie kredy, tablicy i wykładowcy. Z drugiej strony pedagogika pozwala połączyć, pozorną w dużej mierze, emancypację kobiet (szczególnie z prowincji), jaką daje możliwość studiowania, $\mathrm{z}$ utwierdzaniem $\mathrm{w}$ tradycyjnych rolach płciowych wspomaganych przez wdrażanie w zawody związane z opiekuństwem.

K.Sz.: Wróćmy jednak z powrotem do analizy klasowej. W Polsce mamy 325 uczelni niepublicznych, w których uczy się 0,66 mln studentów: to w skali europejskiej dość wysoki wynik. Jakie funkcje w zaostrzaniu i podtrzymywaniu nierówności społecznych pelni ten rodzaj szkolnictwa?

A.N.: Ważnym aspektem funkcjonowania szkolnictwa wyższego po 1989 roku, szczególnie masowego szkolnictwa prywatnego, jest wygaszanie buntu klasowego. Dzieje się tak na kilku płaszczyznach. Po pierwsze, szkolnictwo wyższe oddala moment przejścia do życia zawodowego w jego pełnym wymiarze, przez co zaniża realną liczbę bezrobotnych. Po drugie, dzięki szkolnictwu wyższemu państwo w ukryty sposób może subwencjonować prywatny biznes. Dotyczy to szczególnie handlu i usług, co z kolei wynika z korzystnych dla pracodawcy warunków zatrudniania studentów/-ek. Po trzecie, szkolnictwo wyższe jest swoistą protezą składek na ubezpieczenie zdrowotne czy emerytalne. Podsumowując: osoby nieposiadające możliwości geograficznych, finansowych, kapitału społecznego, kulturowego wystarczających, aby studiować na bezpłatnych państwowych studiach, finansują własne ukryte bezrobocie.

Szkolnictwo prywatne i zaoczne przyśpiesza tworzenie podziałów klasowych poprzez specyficzny mechanizm. Osoby studiujące w ten sposób finansowały zarówno własne studia, jak $\mathrm{i}$ - z obciążeń podatkowych - studia uprzywilejowanych kolegów i koleżanek w dziennym szkolnictwie państwowym. To podwójne opłacanie studiów utrudnia gromadzenie kapitału tym, którzy i tak nie mieli go wystarczająco dużo, aby podjąc dzienne darmowe 
studia, a ułatwia z kolei akumulację kapitału szkołom niepublicznym. Te, w większości zaoczne, ściśle zawodowe, bez własnej kadry, nie są pasem transmisyjnym wartości kulturowych. Studenci tych szkół w żaden sposób nie pomnażają kapitału kulturowego czy społecznego. Uniwersytety nie zmieniają światopoglądu, wartości, nie przekształcają gustów estetycznych, sposobów zachowania. Bez tego nie mogą w żadnym stopniu stanowić katalizatora zmiany społecznej. Szkoły te nie wykształcają drogiej mi „formacji” akademickiej, specyficznego habitusu, wzorów działania. Widoczne jest to w nikłej obecności czegoś specyficznego, co określano mianem kultury studenckiej. Przykładem mi bliskim, wskazującym na ów zanik, jest zniknięcie z mapy akademickiego Poznania Dyskusyjnych Klubów Filmowych.

\section{K.Sz.: Czy szkolnictwo wyższe uczestniczy dziś w neoliberalnym demontażu państwa?}

A.N.: Oczywiście. Warto zauważyć ukrytą neoliberalną strategię rozmontowywania państwa i przenoszenia odpowiedzialności na jednostki. Szkolnictwo prywatne zapewnia możliwość dodatkowego zarobku pracownikom uczelni państwowych. Widać tu, w jaki sposób pasożytuje ono na państwie. Szkolnictwo prywatne transferuje pieniądze od studentów do wykładowców, w ten sposób niskie nakłady na naukę nie powodują niezadowolenia środowisk naukowych. $Z$ drugiej strony szkolnictwo prywatne może osiagać całkowicie prywatne zyski, nie ponosząc kosztów kształcenia kadry i wykorzystując jej potencjał zawodowy, intelektualny etc.

K.Sz.: Neoliberalny uniwersytet jest zatem poprzecinany różnymi liniami podziału, najważniejszym $z$ nich jest zapewne podzial klasowy. Nie różni się $w$ tym zatem od społeczeństwa, w ramach którego funkcjonuje...

A.N.: Widać to szczególnie, gdy odnotujemy, w jaki sposób w strukturze uniwersytetu odbijają się „różne prędkości” funkcjonowania jego pracowników. Szczególnie zauważalne jest to w statusie doktorantów. Ewoluował on od kategorii asystentów zatrudnionych na etat do kategorii studentów trzeciego stopnia, mających zupełnie niejasną pozycję. Warto zauważyć brak poczucia bezpieczeństwa ontologicznego, jaki stał się ich udziałem. Można w tym miejscu przywołać analizy konsekwencji pracy elastycznej dokonane przez Richarda Sennetta w książce Korozja charakteru: osobiste konsekwencje pracy w późnym kapitalizmie.

K.Sz.: Ostatnie protesty doktorantów we Wroclawiu, domagających się godnego traktowania i podniesienia wysokości stypendiów, rzuciły kolejne światło na ten problem.

A.N.: Warto bliżej przyjrzeć się ich sytuacji. Trzeba jasno stwierdzić, iż doktoranci są potrzebni do odtwarzania struktury i warunkują rozwój kadry naukowej. Doktorant/-ka są 
www.praktykateoretyczna.pl

postawieni w sytuacji totalnej niepewności, dotyczy to zarówno przyszłego zatrudnienia, jak i realnego otrzymywania stypendium doktoranckiego. Sytuację doktorantek świetnie ilustruje fakt, iż do niedawna (2006 rok) ${ }^{2}$ nie było możliwości pójścia na urlop macierzyński w trakcie studiów doktoranckich. Ewentualna przerwa w studiach była przyznawana uznaniowo oraz często oznaczała nieotrzymywanie stypendium. Jednak nawet po zmianie przepisów doktorantka $\mathrm{w}$ ciąży jest postawiona $\mathrm{w}$ sytuacji, w której powinna napisać wniosek do prorektora z prośbą o niewstrzymywanie stypendium na czas trwania urlopu macierzyńskiego. Wniosek taki musi mieć akceptację kierownika studiów doktoranckich. Doktoranci to siła robocza pozbawiona bezpieczeństwa ontologicznego i przywilejów pracowniczych, wykonują oni normalne obowiązki dydaktyczne, a nie mają nawet szans na ochronę, jakiej podlegają pracownicy. Dodatkowo doktoranci w swym potencjalnym oporze spacyfikowani są przez perspektywę obrony pracy doktorskiej i wizję starań o etat. Możliwość uzyskania pracy w równorzędnym ośrodku akademickim poza miejscem zamieszkania jest perspektywą efemeryczna. Niepewne stypendium doktoranckie, niejasność kryteriów, brak zapewnianej przez uczelnie bazy mieszkaniowej i ceny mieszkań w dużych miastach skutecznie blokują możliwość awansu społecznego, tzn. robienia kariery naukowej przez ludzi ze wsi i małych miast. Dochodzą do tego nierówności pomiędzy dawnym feudalnym uniwersytetem z PRL a nowym wyzwaniem kapitalistycznym. Istnieje wielka różnica pomiędzy adiunktem zatrudnionym dawniej na etat nieograniczony a umową okresową młodszego adiunkta czy stypendium doktoranckim odnawianym co rok. Osoba z umową na czas nieograniczony nie podlega w takim stopniu presji rynkowej, jak osoby z umowami okresowymi czy doktoranci. Jak w takich warunkach odtwarzać kadrę naukową? Osobną kwestią jest natomiast podział na pracowników nauki i personel, nazwijmy go pomocniczym (bibliotekarze, portierzy, administracja etc.), oraz uposażenie administracji.

K.Sz.: Dziś przystosowanie uczelni do modelu gospodarki opartej na wiedzy stało się priorytetem. Jednak jej wizja, w oparciu o którą kierują się autorzy ostatnio proponowanych strategii rozwoju szkolnictwa wyższego, wydaje się dość anachroniczna: adekwatna byłaby pewnie dla Stanów Zjednoczonych w latach osiemdziesiątych. Wybór jest dziś pomiędzy mniejszym a większym zlem. Konferencja Rektorów Akademickich Szkół Polskich rozwiązalaby problemy szkolnictwa wyższego przez wprowadzenie powszechnego czesnego, konsorcjum Ernst \& Young natomiast poprzez zaaplikowanie zasad konkurencji rynkowej we wszystkich sferach aktywności akademii od dydaktyki

\footnotetext{
${ }^{2}$ Przepis ten zmieniło dopiero Rozporządzenie Ministra Nauki i Szkolnictwa Wyższego z dnia 19.12.2006 r., http://krd.org.pl/modules/articles/index.php?cat_id=7
} 
po działalność badawczą. Jak ocenia Pan kierunek, w którym zmierzają nieuchronne zmiany?

A.N.: W artykule Co z uczelniami?: sq strategie...rozważne $i$ romantyczne Magdy Papuzińskiej w „Polityce”3 pada krytyczna diagnoza obu propozycji reform. Ocenione są one jako romantyczne, gdyż propozycja Konferencji Rektorów Akademickich Szkół Polskich jest postrzegana przez autorkę jako romantyczna wizja przeszłości akademickiej. Z kolei propozycja firmy Ernst \& Young oceniona została jako romantyczna, wyidealizowana wizja rynku. Muszę przyznać, że z tych dwu wizji wolę romantyzm spojrzenia w przeszłość i ewolucyjną propozycję sformułowaną przez Konferencję Rektorów. W obu strategiach jest wiele punktów godnych uwagi. Niestety radykalne urynkowienie i zapatrzenie w model szkolnictwa amerykańskiego propozycji sformułowanej przez firmę Ernst \& Young grozi moim zdaniem kompletną zapaścią szkolnictwa wyższego. Oczywiście proponowane w tym raporcie uelastycznienie, przejrzystość procesu oceny są mi bliskie. Nie rozumiem jednakże, dlaczego kategorie te rozumiane są jako pochodne procesu rynkowego. Dziś wiemy, choćby dzięki lekturze Doktryny szoku Naomi Klein i po doświadczeniach zaangażowania Polski w Iraku, że radykalne, rewolucyjne, „romantyczne” reformy urynkowiające dalekie są od przejrzystości i upodmiotowienia ich uczestników. Warto w tym momencie pamiętać o ocenie polskiej transformacji dokonanej przez profesora naszego Uniwersytetu Jacka Tittenbruna.

K.Sz.: Czy jednak, mimo wszystko, wysoki poziom skolaryzacji (dziś studiuje 40,2\% populacji w wieku 19-24 lata) nie móglby pociągnąć za sobą wzrostu aspiracji emancypacyjnych wśród polskiej młodzieży?

A.N.: Maciej Gdula w swoim tekście Czekajac na $\mathrm{maj}^{4}$ chciał wskazać na pewne paralele pomiędzy sytuacją paryskiego maja 1968 roku a Polską po 2000 roku. Podobieństwa upatruje on w tym, że oto i tu, i tam mamy do czynienia z nadprodukcją wykształconej młodzieży, której nie oferuje się perspektyw adekwatnych do jej możliwości. Gdula wskazuje na fakt, iż rosnąca frustracja fikcyjnego pokolenia może przerodzić się w ruch, wybuch społeczny. Niestety nie ma w tym racji. Wynika to przynajmniej z kilku powodów: po pierwsze, odmienny jest kontekst ideologiczny, od dominującej hegemonii neoliberalnej po absolutny indyferentyzm polityczny polskich studentów. Po drugie, gniew klasowy jest neutralizowany w dużej mierze przez masową emigrację. Po trzecie, jest on wygaszany przez funkcjonalny wobec neoliberalizmu neotradycjonalizm. Jest on reakcją obronną na fakt ujednostkowienia

\footnotetext{
${ }^{3}$ M. Papuzińska, Co z uczelniami?: sq strategie...rozważne i romantyczne, „Polityka” 2010, nr 8 (2744), s. 2830 .

${ }^{4}$ M. Gdula, Czekajac na Maj, „Krytyka Polityczna” 2004, nr 6, s. 58-64.
} 
www.praktykateoretyczna.pl

pozbawionego momentu upodmiotowienia. Niestety szukanie rozwiązań w mglistej obietnicy konserwatywnej wspólnoty, na przykład w ramach środowisk skupionych wokół pisma „Fronda”, nie jest rewolucją o której myślał Gdula. Po czwarte, jak wskazywałem wyżej, większość studentów uczy się na studiach zaocznych i prywatnych. Nie są oni w stanie wykształcić w sobie odpowiedniej uniwersyteckiej, akademickiej formacji/habituacji. Osoby te w dużej mierze nawet jeśli poczują się oszukane przez system edukacyjny, nie będą miały możliwości przebić się ze swym głosem. Znaczna cześć studentów/-ek potraktuje studia wyższe często bardzo cynicznie, jako mniej lub bardziej udany wpis w CV.

Ze smutkiem przychodzi mi zakończyć niniejszą rozmowę - polskiego maja 1968 nie będzie. 